\title{
Resilience strategies in the face of short- and long-term change: out- migration and fisheries regulation in Alaskan fishing communities
}

\author{
Amber Himes-Cornell $^{1}$ and Kristin Hoelting ${ }^{2}$
}

\begin{abstract}
Historically, communities persisted in remote, isolated areas of Alaska in large part because of the abundance of marine and terrestrial resources, as well as the ability of local people to opportunistically access those resources as they became available. Species switching and the ability to shift effort away from fisheries during poor years allowed local residents to diversify their livelihoods in the face of uncertainties and ecological change. The advent of modern fisheries management, which views Alaskan fisheries as the property of all citizens of the United States, has fundamentally altered the relationship of place-based communities to fishery resources. Local access to fisheries has been particularly affected by the development of transferable fishing privileges, making it possible for fishing rights to leave place-based communities through the choices of individual community members to sell or to move away. When fishing communities in Alaska lose active fishing businesses, over time the loss of various types of community capital will follow, including human, social, cultural, technical, and financial capital. In some cases, communities are able to adapt or transform through diversification of their local economies. In other cases, no alternatives to a fishery-based economy are accessible. We have used resilience theory to explore drivers of change affecting Alaskan fishing communities. Emphasis was placed on two primary change drivers, the regulatory environment and rural out-migration, as well as their interconnections and their impacts on individuals, communities, and the larger social-ecological system. We summarized several government programs that have been implemented to support the continued participation of communities in Alaskan fisheries. In addition, we reviewed informal and private-sector efforts to generate resilience strategies that can facilitate new entry into fisheries or retain fishing businesses and fishing rights within communities, as well as respond to increasing uncertainty related to the global market and climate changes.
\end{abstract}

Key Words: Alaska; communities; fisheries privatization; out-migration; resilience; well-being

\section{INTRODUCTION}

An increasing array of factors is driving rapid change and restructuring in many communities in Alaska. In the case of fishing-dependent communities, residents have long been accustomed to ecological uncertainty related to stochastic and cyclical changes in resource abundance, extreme weather events, and changes in weather patterns (Langdon 1995, Berkes and Jolly 2001). Moreover, since the advent of commercial fisheries, fishing communities have also faced the economic uncertainty of price and market fluctuations (Morrissey 2008). An array of new ecological, economic, and political uncertainties have arisen in the past half century in the form of climate change, overfishing, growing demand for access to fisheries resources by diverse user groups, a shifting regulatory environment, and variable market conditions (Mederer and Barker 2000, Mantua and Francis 2004, Donkersloot 2005, Morrissey 2008). In addition, Alaskan fishing communities are affected by the same large-scale socioeconomic and cultural forces faced by rural communities throughout the world that drive out-migration and overall population declines (Hadland 2004, Huskey et al. 2004, Martin et al. 2008, DCCED 2009, Howe 2009, Huskey 2009, Martin 2009, Lowe 2012, ADL 2013).

Throughout history, individual fishers and fishing communities as social units have relied on resilience strategies that allowed them to weather fishing-related uncertainties. In situ resilience strategies that have historically provided a flexible, resilient way of life include diversification of target species, species and gear switching, technological innovations, and rationing in times of scarcity (Allison and Ellis 2001, Marschke and Berkes 2006, Kasperski and Holland 2013). When none of these in situ strategies were available or sufficient, communities relied on seasonal and longer term "adaptive migration," moving together to new locations (Langdon 1995, Berardi 1999, Huskey et al. 2004, McLeman 2011, Package-Ward and Himes-Cornell 2014).

Following the U.S. purchase of Alaska in 1867, life in rural Alaska began to change dramatically. In the late 1800 s and early 1900 s, the development of infrastructure to provide government services such as education and health care more definitively linked communities of people to permanent settlements (Berardi 1999), increasing the importance of in situ resilience strategies for longterm community survival. Between the late 1800s and mid-1900s, the federal and state governments began to manage fishery resources on behalf of all U.S. citizens (Macinko 1993, Bader 1998), setting the stage for a shift in the relationship between place-based communities and access to their local resource base. Beginning in the 1970s, management of fisheries transitioned from open access to limited access and frequently toward private, transferable fishing privileges. For the first time, the potential existed for a fishing community in Alaska to lose access to commercial fisheries, i.e., retain no active fishing participants if individual permit holders or quota shareholders chose to sell the privileges and/or out-migrate from the community (Bjarnason and Thorlindsson 2006, McLeman 2011). Rural Alaskan communities have experienced significant out-migration and population declines since approximately 1990 (DCCED 2009) resulting from numerous shifts in socio-cultural, economic, ecological, and regulatory systems (Martin 2009, Lowe 2012). In fact, many scholars have demonstrated that the loss of active fishing businesses and fishing-related employment opportunities plays a key role in this process; the economic and cultural viability 
of many Alaskan communities are intimately linked to local fishing participation (Donkersloot 2005, Clay 2007, Carothers 2008, Clay and Olson 2008, Langdon 2008, Carothers et al. 2010).

We contribute to the literature by using resilience theory to explore drivers of change affecting Alaskan fishing communities. Emphasis is placed on (1) rural out-migration and (2) fisheries access, their interconnections, and their impacts on individuals, communities, and the larger social-ecological system (SES). We then summarize several government programs that have been implemented to support community access to fisheries. Finally, we review informal and private-sector efforts to generate "new resilience strategies" that can facilitate new entry into fisheries by community members or retain fishing businesses and fishing rights within communities, as well as respond to increasing uncertainty related to the global market and climate changes.

\section{WHAT IS RESILIENCE?}

In terms of the dynamics of fishing community resilience, we consider three distinct layers of the system concurrently: the fishing community as a social unit, the individuals that make up the community, and the overall SES, defined as an integrated system involving ecological and social dimensions (http://www. stockholmresilience.org/21/research/what-is-resilience/resiliencedictionary.html). To examine each of these distinct layers, a brief review of the distinct conceptualizations of resilience is necessary. Resilience is present in the concept of "persistence," the likelihood that an ecological system or SES will persist in its present stability domain rather than crossing a threshold into an alternative state (Holling and Gunderson 2002, Folke et al. 2010). However, this resilience framework also incorporates elements of adaptability, i.e., the capacity of actors in a system to influence resilience, and transformability, i.e., the capacity to create a fundamentally new system when ecological, economic, social, or political conditions make the existing system untenable (Walker et al. 2004). Considering persistability, adaptability, and transformability side by side allows for improved consideration of resilience overall, including human agency, power dynamics, justice, equality, and well-being within social systems (Davidson 2010, Folke et al. 2010, Coulthard 2012, Keck and Sakdapolrak 2013).

The term resilience has been conceptualized differently in various fields (Brand and Jax 2007, Martin-Breen and Anderies 2011). At its most basic, resilience is used in the field of engineering to refer to the ability of a material to resist external forces, shocks, and disturbances and to quickly return to its normal state (Martin-Breen and Anderies 2011). Furthermore, considering the context of individuals and their interactions with their families and larger communities, an individual's "psychological resilience" is defined as "a person's ability to use available resources to overcome stress and adversity" (Kirmayer et al. 2009:63). The resources available to an individual may include personal traits, such as self-esteem, cognitive and problem-solving abilities, health, appearance, and temperament; social relationships, including the ability to seek comfort, support, and/or inspiration from other individuals; and personal beliefs, meaning, and selfknowledge (Kirmayer et al. 2009).

Scholarship on community resilience has largely focused on the resources a community possesses, i.e., "community capital," and the degree to which the community can collectively develop and engage these resources to improve well-being (Magis 2010). Broad categories of community capital include the following: natural capital, i.e., natural resources and ecosystem services; social capital, i.e., relationships and connections between community members and between community members and the outside world; cultural capital, i.e., shared traditions, beliefs, and values that increase social cohesion; human capital, i.e., the skill sets and knowledge base of the population that can contribute to creative problem solving; political capital, i.e., the presence of functioning institutions and the ability of community members to influence the outcome of decisions that affect them; built capital, i.e., infrastructure and other physical resources in the community; and financial capital, i.e., assets and access to financing mechanisms (Emery and Flora 2006, Rolfe 2006, Kirmayer et al. 2009, Magis 2010).

An individual's personal resilience strategy has the potential to increase community resilience if he/she has resources to add to the community's capital. However, an individual's personal resilience strategy may involve migration when opportunities are not available locally or when opportunities in other locations are more attractive. In such cases, resilience at the individual level has the potential to undermine community resilience through contributing to overall population decline and loss of the resources an individual contributes to the larger community. Given this, resilience at one level of a system may not correlate to resilience at another level (Marshall et al. 2007, Robards and Greenberg 2007, Kirmayer et al. 2009). The resilience of a community as a social unit is dependent on the personal attributes and choices of the individuals that make up that community, as well as the ecological functioning of the SES. The well-being of individuals is impacted by the overall functioning of the community unit and SES, as well as opportunities available to them both locally and elsewhere. In the context of Alaskan fishing communities, the resilience of the overarching fishery SES depends on the persistability and adaptability of the community and the fishery resource base.

\section{"FISHING COMMUNITY," "FISHERY SOCIAL- ECOLOGICAL SYSTEM,” AND FISHERY ACCESS}

The importance of sustaining the participation of place-based fishing communities in the fisheries is recognized within the Magnuson-Stevens Fishery Conservation and Management Act (MSFCMA) by National Standard 8 [16 U.S.C. § 1851(a)(8)]. The concept of a fishing community is legally defined in the MSFCMA as a community that is "substantially dependent on or substantially engaged in the harvest or processing of fishery resources to meet social and economic needs, and includes fishing vessel owners, operators, and crew and United States fish processors that are based in such community" [16 U.S.C. $1802 \S 3$ (17)]. The definition is further clarified in the MSFCMA's National Standards Guidelines as "a social or economic group whose members reside in a specific location and share a common dependency on commercial, recreational, or subsistence fishing or on directly related fisheries dependent services and industries (e.g., boatyards, ice suppliers, tackle shops)" [50 C.F.R. Ch. VI (10-1-02 edition) $\S 600.345$ (b)(3), p. 43]. In addition, National Standard 8 states that all conservation and management measures shall "take into account the importance of fishery resources to fishing communities by utilizing economic and social data to ... A) provide for the sustained participation of such communities, and B) to the extent practicable, minimize adverse economic impacts on such communities." 
Fig. 1. Nested systems within a fishery social-ecological system.

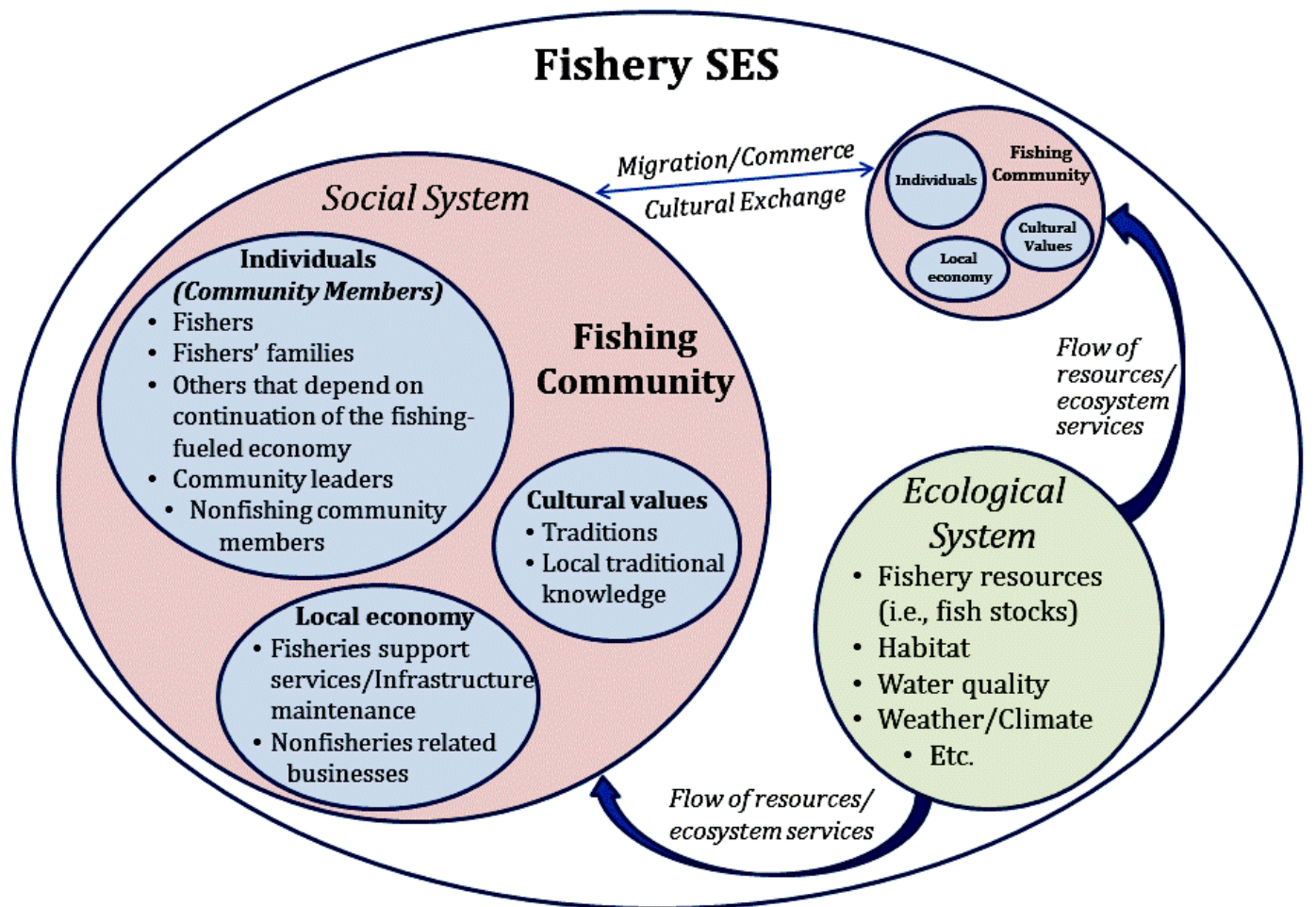

Thus, in the context of federal fisheries management in the United States, a "fishing community" under the MSFCMA is place based and can be defined as a group of individuals and families residing in a specific locality, where one or more types of fishing are central to the economic well-being and social fabric of the community (Clay 2007, Clay and Olson 2008). This definition embeds such communities within a fishery SES. The SES model has been applied to the study of systems at many different scales. As illustrated in Figure 1, we specifically look at a simplistic view of this model at the scale of the individual place-based community and its relationship to other fishing communities and fishery resources within a fishery SES. The social system is considered to include one or more communities and their community members, as well as economic and cultural dimensions, whereas the ecological system includes the fishery resources the communities depend on, individuals that harvest them, and the ecosystem components that allow those resources to thrive, e.g., clean water and adequate habitat. The fishery SES also includes migration of individuals and the flow of goods and other commercial services between communities. Although not depicted in Figure 1, a fishery SES may also include members of place-based communities that participate in fisheries farther away from the community or across multiple ecological systems.

Resilience of both the fishing community as a social unit and individual community members is tightly linked to the resilience of the overall fishery SES. The definition of fishing community outlined previously suggests that without continued dependence on and engagement in fishing, the community would be transformed into an alternate state, either continuing in a different type of fishery SES or potentially no longer constituting a fishing community (Jentoft 2000, Robards and Greenberg 2007, ReedyMaschner and Maschner 2013). It follows that individual members of the community are also embedded within the fishery SES, as fishers, individuals who develop and maintain community infrastructure and provide fishing support services, or other individuals whose well-being depends on the persistence of the fishery SES. In larger, more economically diverse communities, e.g., Anchorage and Seattle, there is also a large segment of the population that is not connected to fishing given the existence of other strong industries, even though the community as a whole is substantially engaged in or dependent on fishing. In this context, we define engagement in fishing as the level of participation by community residents in a fishery or set of fisheries with the SES as a whole, whereas we define dependence on fishing as a measurement of what percentage of people in a community participate in fishing to support their livelihoods.

\section{STRESSORS AND PERTURBATIONS: DRIVERS OF CHANGE}

SES stability is affected by drivers of change across different timescales and different rates. First, stressors, i.e., long-term, continuous, slowly increasing threats, can be distinguished from perturbations, i.e., rapid onset threats of shorter duration (Turner et al. 2003, Keck and Sakdapolrak 2013). A related concept is captured within the notion of panarchy, or multiple levels of stressors and perturbations that interact with both the human and natural systems. In panarchy, small, fast variables at the bottom of the hierarchy create change in the system of interest, whereas large, slow variables at the top of the hierarchy can constrain the latitude of change in the system, helping it 
Fig. 2. Examples of the dynamics of stressors and perturbations acting on components of an Alaska fishery social-ecological system.

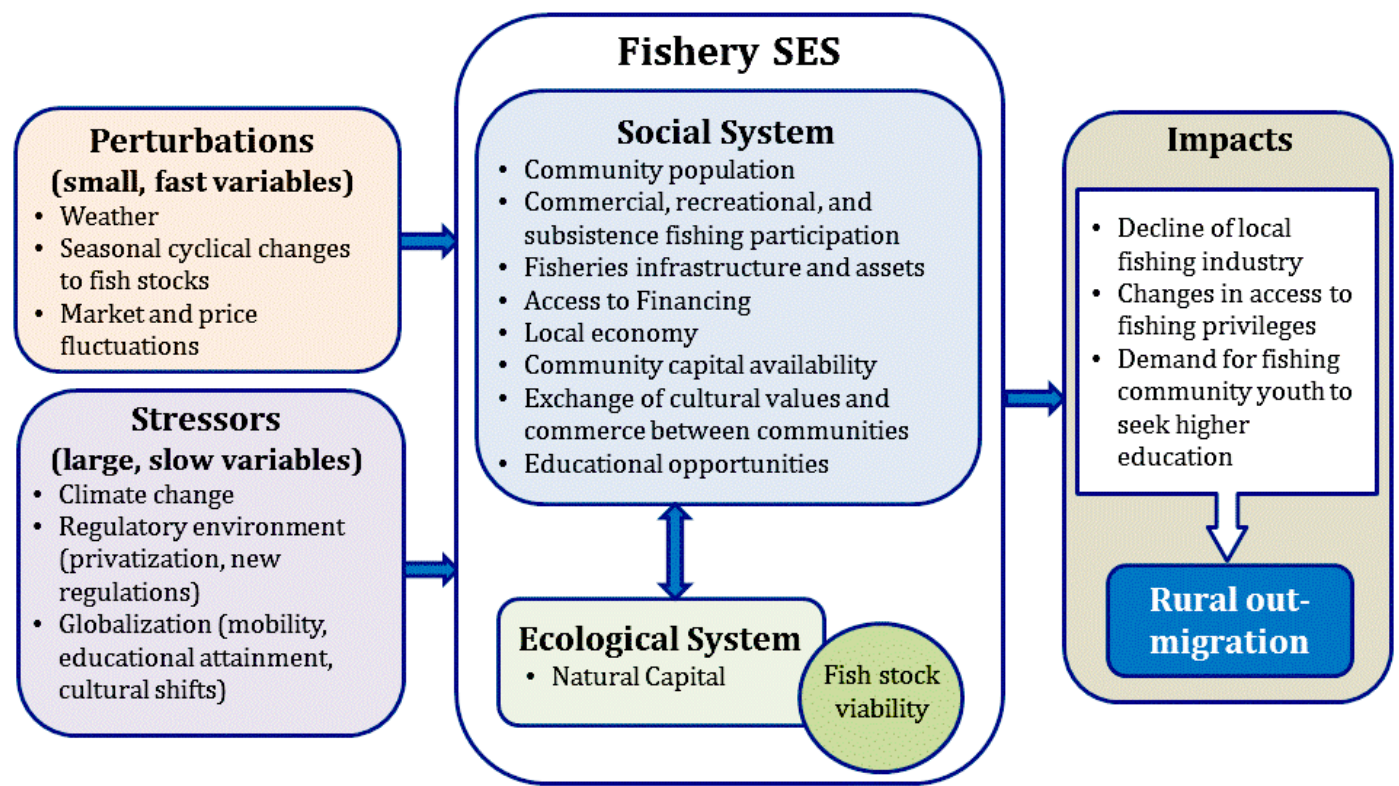

absorb smaller scale shocks while retaining the overall functioning of the original state (Holling and Gunderson 2002). A combination of stressors and perturbations has the potential to push the system of interest beyond a threshold from one stable state of form and function to another. If large, slow variables undergo a regime shift, the potential exists for an irreversible shift from one stability domain to another (Scheffer et al. 2001). In such cases, the conditions may no longer be present for a shift back to the original functioning of the system.

As illustrated in an example in Figure 2, stressors and perturbations acting on fishery SESs in the context of Alaska come from a variety of sources, including the ecological, economic, socio-cultural, and political domains (Mantua and Francis 2004, Carothers 2008, Morrissey 2008, Black et al. 2011). For example, climate change can be considered a slow ecological variable, and a large-scale system stressor, whereas temporary changes in weather patterns can be seen as small-scale perturbations that change quickly. Likewise, natural cycles in ocean conditions that affect the size of a stock of fish in the shorter term would best be characterized as short-term perturbations, e.g., upwelling. Globalization is a large-scale economic and socio-cultural stressor. It drives large-scale sociocultural changes that influence the choices and opportunities available to individual community members, affecting the size and composition of a community's population. Similarly, market fluctuations are largely determined by global demand, affecting the prices paid to fishers locally and occurring on a daily basis. Regulatory environments that affect the ability of residents to participate in fisheries, such as the shift to private, transferable fishing privileges, can be viewed as political stressors that are felt over the long term. These stressors and perturbations are likely to act on multiple facets of the fishery SES, from the social system, e.g., community population levels, fishing participation, various types of community capital, and so forth, to the ecological system, e.g., fish stock viability. As a result, Alaskan communities may be affected by a decline in the local fishing industry, changes in access to the fishing privileges, and increased demands for youth to gain higher education rather than enter the fisheries, as well as other impacts. If stressors and perturbations are not reversed or mitigated, these impacts are likely to cause an increase in outmigration from Alaska's small, rural fishing communities (Carothers 2008, 2010).

The stressors and perturbations acting on Alaskan fishing communities and the larger fishery SES can also be characterized as sources of uncertainty. As noted in the Introduction, residents of fishing communities have long been accustomed to "traditional" forms of uncertainty, such as random and cyclical changes in fisheries, extreme weather events, and unpredictable prices paid to fishers for their catch. However, shifts in large-scale variables, e.g., climate change, cultural and economic globalization, and the regulatory environment, have introduced novel forms of uncertainty that present greater, sometimes irreversible change at the community level.

\section{OUT-MIGRATION FROM ALASKAN COMMUNITIES}

One of the most critical issues facing rural Alaskan fishing communities today is population decline, a process that can undermine the resilience of rural communities, both in the sense of a community's persistability and in terms of the resources it possesses to enable adaptability. Population dynamics are impacted by many interrelated variables, as illustrated by the multiple connections in Figure 2. Rural out-migration is not unique to Alaska; it is a well-documented and long-standing phenomenon in many areas around the world (e.g., Hamilton and Otterstad 1998, Hamilton and Haedrich 1999, Hamilton et al. 2004, Stockdale 2004, Bjarnason and Thorlindsson 2006, Fowler 
and Etchegary 2008, Robson and Nayak 2010, Black et al. 2011, McLeman 2011). In general, though, out-migration rates from Alaska's rural areas are much higher than the national average (Hadland 2004, NPFMC 2007, DCCED 2009, Howe 2009, ADL 2013). Factors driving out-migration from Alaskan fishing communities have been noted to include the following: declining opportunities in fisheries, attributable in large part to the flight of fishing rights away from local communities (Knapp 2011, Lowe 2012, Carothers 2013); limited opportunities for alternative employment in many areas and concomitant seeking out of employment opportunities elsewhere (Huskey et al. 2004, Robards and Greenberg 2007, Howe 2009, Huskey 2009, Lowe 2012); increasing uncertainty related to climate change (Mantua and Francis 2004); increased cost of living (Martin 2009); a desire to escape the social problems that plague many Alaskan communities (Martin et al. 2008); shifting values of younger generations of Alaskans (Langdon 2008, Carothers et al. 2010); increased emphasis on higher education that does not directly prepare youth for life in a fishing community and instead may allow them or require them to find employment elsewhere (Corbett 2004, 2005, Lowe 2012); and increased social and occupational mobility in general (Hamilton et al. 2004, Bjarnason and Thorlindsson 2006, Martin 2009).

\section{PLACE-BASED ALASKAN COMMUNITIES AND CHANGING ACCESS TO FISHERIES}

Beginning in the 1970s, management of Alaskan fisheries shifted from open access to limited access to resolve a number of biological and socioeconomic problems and to meet fisheries management goals set out in the National Standards of the MSFCMA (Donkersloot 2006, Hilborn 2007). In the United States, limitations on access are achieved either through restrictions on the total number of permits issued and/or through catch share programs that create transferable fishing privileges, i.e., quota shares, that are associated with a percentage of the annual total allowable catch that individuals or other entities are allowed to harvest (Graton et al. 1996, Yandle and Dewees 2003, Mansfield 2004). The creation of catch share programs, in particular, has been heralded as a solution to the economic inefficiency and poor incentive structure of open-access arrangements (Gordon 1954, Scott 1955, Clark 1980, Costello et al. 2008).

In Alaska, the move to private, transferable fishing privileges resulted in many socioeconomic benefits for those individuals who initially received a permit or quota allocation based on their historical participation in a fishery. Particularly in the case of catch share fisheries, there is increased flexibility, safety, and profitability for those individuals who do hold quota share (Fina 2011; cf. Windle et al. 2008) and longer term, more stable employment for the remaining crew positions (Abbott et al. 2010; cf. Olson 2011). Further, for those who receive permits or quota shares during initial allocations, the fishing rights often become a highly valuable asset that can be sold or leased for cash or leveraged for additional investment. In other words, those individuals have increased resources available to them, increasing their personal resilience and creating an opportunity to contribute to the resilience of their community.

At the same time, the move toward private, transferable fishing rights has raised important questions of social equity and resilience at the scale of the fishing community overall. There is an "inherent tension between the economic goal of maximizing efficiency and the social goal of protecting communities or facilitating new entry [of fishers]" (GAO 2004:15; see also Carothers 2008, 2010, 2011, 2013, Langdon 2008, Lowe 2008, Carothers et al. 2010, Clay et al. 2010, Olson 2011, Carothers and Chambers 2012). The higher cost of fishing privileges has contributed to difficulty in retaining fishing rights and intact fishing businesses within Alaskan fishing communities (Rice 2006, Rosvold 2007, Carothers 2008, 2011, 2013, Langdon 2008, Lowe 2008, Carothers et al. 2010, Knapp 2011, Carothers and Chambers 2012). In addition, the increased cost to enter and compete in individual fisheries presents a "barrier to entry" for potential new fishers, and fishing rights sold by community members are likely to be purchased by outside investors with greater access to capital (Donkersloot 2006, Fina 2011). Other key socioeconomic impacts include overall loss of employment opportunities, particularly the total number of crew positions (Lowe 2008, Fina 2011), lower percentages paid to crew members (Pinkerton and Edwards 2009), and difficulty transferring intact fishing businesses from retiring fishers to younger community members (Rice 2006, Rosvold 2007).

Whether fishing privileges are retained at the community level depends on the choices of individual fishers holding those privileges. Although many fishers may choose to remain in their local communities and continue to contribute to the local economy, the transferable nature of these privileges opens the door for fishing rights to be removed from the place-based community through transfer to a nonresident owner or through out-migration of the permit holder or quota shareholder him/ herself (Homan 2007, Knapp 2007, Langdon 2008, Carothers 2013). When fishing privileges and active fishing businesses leave a community, in situ resilience strategies are removed and community residents are less able to utilize the commercial value of their local resource base opportunistically. Further, the cost of species switching has increased, as large capital investments are now required if an individual fisher wishes to diversify (Allison and Ellis 2001, NPFMC 2007, Langdon 2008, Lowe 2008, Carothers 2010). Kasperski and Holland (2013) provide evidence of this on the West Coast and in Alaska, where the fleet of vessels active in 2010 had on average a less diverse portfolio of target species than at any point since 1981.

As Carothers and Chambers (2012) and Carothers (2010) point out, the privatization model views fishers as rational, profitmaximizing actors and excludes other culturally distinct ideas of what it means to be a fisher and to derive one's livelihood from fisheries resources. Specifically, a disproportionate loss of fishing rights from smaller, predominantly Native villages has been attributed to a higher discount rate used by individuals in rural villages when making decisions about current cash flow opportunities compared to potential future earnings; poverty that has necessitated sale of capital holdings during periods of financial hardship, e.g., quota shares and limited entry permits; inability to qualify for loans; and lack of access to financial institutions or knowledge regarding the market (Carothers 2008, 2013, Langdon 2008, Reedy-Maschner 2008, Carothers et al. 2010, Knapp 2011). In addition, this model has led to consolidation of fishing rights to those who already have successful fishing businesses or possess a highly entrepreneurial 
value system (Greer 1995). The values embodied by this privatization model work against commercial "lifestyle fishers," who have historically engaged in fisheries opportunistically to maintain a viable livelihood in remote, isolated locations where few alternative economic opportunities are available, as well as subsistence-dependent communities that prefer to intermingle both commercial and subsistence harvests (Carothers 2008, Langdon 2008, Lowe 2008).

Declining access to fisheries is of particular concern in remote communities where few alternative jobs are available (NPFMC 2007, Langdon 2008, Carothers 2010). Under such circumstances, in which economic transformation may not be a viable scenario, long-term community survival continues to depend on the persistability of the fishery SES. Beyond commercial fisheries, a majority of rural Alaskan fishing communities also depend heavily on subsistence harvest of both marine and terrestrial animals to counteract a high cost of living (Martin et al. 2008, Himes-Cornell et al. 2013) and to fulfill traditional and customary uses. In Alaska, as elsewhere (Corbett 2004, 2005, Clay 2007, Clay and Olson 2008), economic and social systems are intertwined with fisheries, and the persistence of human settlements has historically been attributable to both highly resilient, i.e., persistent, fisheries SESs and the adaptive capacity of fishing communities to survive within the bounds of the fishery-based economy available to them.

\section{RESILIENCE STRATEGIES AT THE LEVEL OF INDIVIDUAL, FISHING COMMUNITY, AND FISHERY SOCIAL-ECOLOGICAL SYSTEM}

As of result of changes in many large-scale variables, Alaskan fishing communities and individuals within them are faced with the need, and in some cases the opportunity, to transform (Folke et al. 2010, Lowe 2012, Clayton 2014). We explore the options currently available to these communities and their residents. Concurrent examination of multiple levels of the fishery SES, i.e., (1) the individual, (2) the fishing community, and (3) the overall SES, reveals a more holistic picture of the dynamics of fishing community resilience, including the degree to which resilience at one level may support or undermine resilience at another (Rolfe 2006, Kirmayer et al. 2009).

\section{Individual resilience strategies}

Individual choices play an increasingly important role in the fate of Alaskan fishing communities and associated fishery SESs, as well as the fate of rural communities throughout the world. With increasing social mobility, individuals from rural communities face the choice of whether to stay and participate in the local economy and culture or migrate to another location (Corbett 2004, 2005, Donkersloot 2005, Bjarnason and Thorlindsson 2006, Huskey 2009, Lowe 2012). In fishing communities where few in situ resilience options are available, residents may choose seasonal, temporary, or permanent migration as a way of expanding their options (Huskey et al. 2004, Bjarnason and Thorlindsson 2006). The strategy that would provide for the greatest individual resilience might take the form of staying in a small community and succeeding despite challenges, or it could mean investing in a new life somewhere else (Bjarnason and Thorlindsson 2006, Marshall and Marshall 2007).

Given that fishing privileges in the United States are commonly allocated to and held by individual fishers, individuals who acquire fishing privileges through the initial allocation process and/or through later purchase of permits or quota shares not only have access to harvest the fishery resources but also possess a valuable asset, and they often have the political power to influence the future of that fishing privilege. When a community member holds these privileges, the choice to remain in the community and employ crew members can increase community resilience through bolstering access to natural capital, as well as increasing financial, human, social, cultural, and technical capital. However, if a fisher chooses to sell his/her permit or quota shares, the fishing privilege is likely to be transferred to an owner residing in a different community (Donkersloot 2006, Carothers et al. 2010, Fina 2011, Knapp 2011, Lowe 2012, Carothers 2013). Likewise, the fisher may choose to out-migrate, taking the fishing privilege out of the community. In these two scenarios, although the individual's resilience may increase as a result of his or her choice, community resilience is diminished through loss of access to natural capital and other community capitals.

Individuals who seek to become new permit holders or quota shareholders face a different set of incentives and options for personal resilience. As the cost of entry into fisheries increases, one choice for prospective fishers is to continue to pursue fishing as a primary occupation and to "cope" with reduced income and increased financial risks, as well as the need to work for many years as crew prior to gaining ownership of a fishing operation, i.e., resilience as persistability. Second, prospective fishers may choose to diversify their role within the fishing community by broadening the number of fisheries in which they participate (Package-Ward and Himes-Cornell 2014), taking on one or more supplemental nonfishing sources of income, or more aggressively participating in fisheries farther away from their home community, i.e., resilience as adaptability. Third, a fisher can choose to exit the fishery and pursue other work in the same community, or he or she may move away from the fishery SES entirely, pursuing alternative educational or professional opportunities elsewhere. These strategies are examples of resilience as transformability (Marshall and Marshall 2007, Lowe 2008, Martin 2008, Healey 2009).

In fishing communities that are integrated into relatively diversified regional economic structures, alternative livelihoods may be accessible in situ. Marshall and Marshall (2007) point to the availability of parallel societal roles such as farming, and Allison and Ellis (2001) highlight the ability of many small-scale fishers to access diverse alternative livelihoods during years when fisheries are not profitable. However, Marshall and Marshall (2007) acknowledge that resilience as transformability is not necessarily relevant in contexts that lack alternative livelihood options, as is the case in highly isolated Alaskan communities not connected to road systems and or proximal to hub communities or urban centers. Further, loss of fishing employment without comparable, appropriate alternative employment opportunities can have serious social, psychological, and health consequences for individuals (Pollnac and Poggie 2006, 2008). In many cases, the nonfishing employment sector of Alaskan communities is entirely composed of government and educational positions, as well as a small business sector that would not be sustained without the presence of the fishing industry as a primary economic driver.

In addition to fisheries access, the choice of whether to stay or go is often influenced by an individual's value system and personal 
identity. Young people growing up in fishing communities are faced with competing notions of success and the inherent discord between ideals of communitarianism and cosmopolitanism. Much of the modern world relies on skills that are transferable, and the cosmopolitan view of success places limited value on the generalist, place-based skills that are required to successfully live and work in a small fishing community (Bjarnason and Thorlindsson 2006). In response to the growing divide between the communitarian and cosmopolitan value systems and skill sets, many parents and teachers encourage students growing up in fishing communities to pursue higher education to diversify their personal skill sets (Lowe 2012). However, higher education is a point of controversy in many fishing communities, as exemplified by research that was conducted in Nova Scotian fishing communities. There, many residents were acutely aware of the ramifications of education; the fate of their communities depends on individuals continuing to choose the fishing way of life and commitment to their community over personal diversification and transferability of skills (Corbett 2004, 2005).

The personal choices available to individual residents of Alaskan fishing communities play a large role in determining the trajectory of the local population and the resilience of the community overall. Migration as an individual resilience strategy has the potential to undermine or support the resilience of the larger community (Bjarnason and Thorlindsson 2006). Migration could signal loss of human capital through the phenomenon of brain drain, resulting in lower resilience as adaptability. Likewise, loss of population over time can undermine a community's ability to persist as a viable locality.

Out-migration, however, is not always permanent, and it is important to note the role of return migrants to Alaskan communities. Those individuals that leave may gain education and job experience and then return, bringing with them increased human capital and links to resources beyond the community. These skills are often needed to run their local governments and effectively utilize community resources to plan for the future development of the community (Huskey et al. 2004, Huskey 2009, Lowe 2012). In addition, individuals that leave may retain strong ties to other community members and, in some cases, provide support networks for one another in other locations (see Portes 1998, McLeman 2011, Package-Ward and Himes-Cornell 2014 on ethnic enclaves) and/or send remittances back to their home communities. Thus, the temporary or even long-term departure of individual community members may not signal a complete loss of the community resources they contributed.

\section{Community resilience strategies}

Resource-dependent communities, such as mining, timber, or fishing towns, are often characterized by single-sector economies based on production of one type of commodity. Because of their lack of diversified economies, such communities are generally less resilient in the face of change; they are subject to boom-and-bust cycles, often coming into existence for a period of decades and ceasing to exist when the resource is exhausted (Winkler et al. 2012). Although fishing communities are subject to the same boom-and-bust cycles that affect other resource-dependent communities, the renewable nature of fisheries resources and the great diversity and resilience of ocean and coastal ecosystems can provide a buffer against shocks to fishing economies. During periods when commercial fishing is not a sufficient income generator, some individuals may shift their focus to subsistence harvesting activities, allowing them to remain in the community rather than migrate (Robards and Alessa 2004).

In the face of declining fishery resources or limitations on fishery access for local residents, community leaders may seek to diversify the local economy so that the fate of the locality is not so directly tied to one industry. Indeed, in the face of global changes that threaten the viability of fisheries around the world, many point to the necessity of economic diversification and expansion into other industries (Clayton 2014). Community leaders may also seek to diversify community revenue sources through federal or state funding for capital projects and community programs or to reduce costs through alternative energy projects. Ultimately, large-scale drivers of change may reduce or remove the viability of place-based fishing livelihoods and communities, forcing communities to transform to survive (Berkes and Seixas 2005, Folke et al. 2010).

Moving forward, to persist, communities may not be able to retain the same structure and function, i.e., resilience as persistability, but instead may need to change, i.e., resilience as adaptability and/ or transformability (Holling and Gunderson 2002). The most resilient communities will be those that both are able to diversify economically and possess the greatest social and cultural capital in the face of stressors placed on the community (Adger 2006). In addition, a community with significant social and/or cultural capital may be able to cope with greater scarcity than a community whose members have lower levels of trust and reciprocity and who do not share a common vision and value system. The most successful communities will also be those that are able to harness available community resources to enhance their own well-being and strategically move into the future (Magis 2010).

Most Alaskan fishing communities are remote. Community leaders face the logistical challenges of their remote, isolated geographies, including high fuel and energy costs that make it difficult to compete with less isolated communities that are better able to exploit economies of scale. In addition, the ability of fisheries resources to support communities across a vast geographic area is not easily replicated by other industries. In short, if the fishing-centered economies and cultures of many Alaskan communities are no longer able to persist in their present form, in many cases no in situ community alternatives will be accessible; community resilience may necessarily suffer through disintegration of the present localities and migration of residents to other locations (Wrathall 2012, Reedy-Maschner and Maschner 2013).

\section{Resilience of Alaskan fishery social-ecological systems}

An Alaskan fishing community, defined as a locality embedded within a fishery SES, can be viewed in two distinct ways. First, isolated, resource-dependent communities may lack access to alternative local economic drivers (Langdon 2008). Second, they are a vibrant intersection of renewable resources and place-based cultures and ways of life (Kelty and Kelty 2011). The first notion highlights the vulnerability of local systems to global processes of markets, climate, ocean dynamics, and cultural shifts. The second notion highlights the resilience of coastal resources that have provided the foundation for centuries of human inhabitation and cultural coevolution. Both ways of conceiving of Alaskan 
fishing communities, and thus Alaskan fishery SESs, hold important truths. However, as the lives of rural Alaskan residents become increasingly integrated with the market economy and reliant on services and technologies provided by outside entities, the impact from outside drivers of change increases in magnitude.

Local residents are keenly aware of the stakes involved in the loss of fishing rights locally, as well as the question of the future economic development of their communities and regions (Carothers 2008). Many communities are polarized by the possibility of transformation away from fishing and toward diversified or alternative employment. There are differing notions within fishing-dependent communities about the degree to which well-being would be served by maintaining the existing economic system and way of life versus moving toward a new system less dependent on the original resource base (Robards and Alessa 2004). As an example, Robards and Greenberg (2007) analyze the resilience of the Bristol Bay salmon fishery SES. They argue that strong resistance from local communities to development of a proposed copper mine (Pebble Mine) reveals the intrinsic resilience of the Bristol Bay salmon fishery SES; many local residents believe that their livelihood and way of life, which is tied to the Bristol Bay salmon fishery, would be threatened by development of the mine. However, the authors point to increasing interest in oil and gas development in the Bristol Bay region as potential evidence of the "weakening of feedbacks stabilizing the wild salmon fishery, and consideration of new system states" (Robards and Greenberg 2007:21).

Community and SES resilience depend on the empowerment of local residents to affect their own well-being and the ability of a community to mobilize its resources toward its own strategic development goals (Magis 2010, Etuk et al. 2012). If a community decides to move toward an economic alternative to fishing, this may reflect overall community resilience, while at the same time it may lead to a transformation of the fishery SES. The elimination of fishing as a livelihood option may not immediately signify the end of the fishery SES; however, it may erode community capital available to facilitate the community's engagement in future fishing opportunities. Langdon (2008) points to loss of technical capital, i.e., expertise regarding how to make, use, and maintain gear and local knowledge of how and where to fish; social capital, i.e., the active network of individuals with established kinship and community relationships, allowing them to work together effectively; and cultural capital, i.e., values, ideas, aspirations, stories, and heritage passed from generation to generation and through the social network. This process is illustrated by the experience of many Kodiak-area villages, where elders often refer to village youth, age 30 and younger, as "the lost generation." These young people are "no longer growing up fishing, they do not share in the fishing identity of their parents or grandparents, and, importantly, most no longer want to be fishermen" (Carothers 2008:16). As a result, they do not possess the skills or the interest necessary to actively participate in the livelihood of a fishing community.

The ability of the fishery SES to adapt and transform may also have to do with how we understand and define the concept of fishing community. Although the term is defined under the MSFCMA to signify a specific geographic locality, it is also important to consider the resilience of the group of people that make up the community, regardless of whether they continue to reside in the same location. Reedy-Maschner and Maschner (2013) provide an important example of community members originating from Sanak, a place that no longer has any year-round population but continues to play an important role in the lives of past residents. They argue that these individuals have shifted from a "place-based" view to a "place-focused" perspective, in which Sanak Island continues to play an integral role in their fishing way of life and sense of identity, despite the fact that access to services and cost of living have made it impossible to continue to live there on a year-round basis. Similarly, the increased ease of transportation, even in isolated areas of Alaska, allows for greater mobility and translocal communities of people that continue to engage with a place despite not living there throughout the year. This increasing flexibility in relationship to place may signal a transformation of one component of the fishery SES, as well as an adaptation of the overall system.

\section{EFFORTS TO SUPPORT AND FACILITATE COMMUNITY RESILIENCE}

Although the advent of transferable fishing privileges has resulted in many economic, ecological, and social benefits, it has also generated concerns regarding the retention of fishing access in rural Alaskan communities, as well as increasing costs for new entrants in fisheries (GAO 2004, Carothers 2008). In recognition of this, fisheries management agencies have implemented a number of programs intended to facilitate retention of fishing rights and fish processing activity at the local level and to alleviate barriers to entry. In Alaska, these have included geographic delivery requirements, as well as several programs designed to allocate fishing rights directly to regional or community entities that manage the fishing rights on behalf of local communities. Fewer methods have been adopted specifically to protect new entrants, although some economic assistance programs are in place (GAO 2004). In addition, a new effort is underway in one Alaskan fishery to provide right of first refusal (ROFR) to select communities for the purchase of processing rights.

Beyond formal policy design and revision, there are increasing efforts outside of fisheries management to develop and foster creative solutions to problems of barriers to entry and difficulty retaining fishing rights within fishing communities (Olson et al. 2014). Many nonprofits, fishing industry groups, and private individuals are proposing and testing new resilience strategies to both strengthen the ability of fishing communities to persist despite challenges and to respond to market fluctuations and climate changes that threaten the viability of the fisheries economy (Mantua and Francis 2004, Rice 2006, Morrissey 2008, Olson 2011, EAC 2013).

Subsequently, we present examples of government programs that have been developed to facilitate increased resilience in the context of Alaskan fishing communities. We also provide examples of creative private-sector and community-based solutions that have been proposed or attempted in the United States and Canada.

\section{Federal government programs}

Regionally held fishing rights: Community Development Quota Program

The Community Development Quota (CDQ) Program was implemented by the North Pacific Fishery Management Council (NPFMC) in 1992 to allocate a portion of the annual pollock harvest directly to groups of Native Alaskan villages that had not 
previously participated in the pollock fishery and that had limited economic opportunities given their geographic isolation. The program included an annual allocation of $7.5 \%$ of the total allowable catch of pollock to 6 newly created regional nonprofit entities representing villages located within 50 miles $(80.5 \mathrm{~km})$ of the coastline in the Bering Sea-Aleutian Islands (BSAI) region (Ginter 1995). This number was later increased to $10 \%$ of the pollock total allowable catch as well as $7.5 \%$ to $20 \%$ of all other Bering Sea commercial fisheries as they transitioned to management under catch share programs throughout the 1990s and 2000s (Ginter 1995, NPFMC 2002, Ginter and Muse 2003, Haynie 2014).

The CDQ Program was envisioned as both a vehicle to increase opportunity for participation in Bering Sea fisheries and as an economic development program. Originally, the CDQ entities were required to utilize revenues from their allocation of Bering Sea fisheries to invest in "fishery-related" activities in their member villages to develop a self-sustaining fisheries economy (NRC 1999, NPFMC 2002). In 2006, this was broadened to allow $20 \%$ of investment to be made up of nonfisheries-related economic development projects in member villages (http:// alaskafisheries.noaa.gov/cdq/cdqprogsummary.pdf).

By design, the CDQ Program has increased the resilience of CDQ communities and the associated fishery SES in various ways. First, it increased the natural capital available to BSAI villages through allocation of a percentage of the fisheries outlined previously to CDQ entities, suggesting increasing potential for the communities and the SES to persist over time. Further, a number of additional community capitals have been gained through the program, leading to increased adaptability. For example, since the program's inception, CDQ entities have become important voices in the NPFMC process, suggesting that political capital has increased over time. The decennial review of the CDQ Program also provides evidence that the adaptability of CDQ communities has increased as a result of the program. The review was based on four criteria: (1) socioeconomic conditions, i.e., changes over the previous decade in population, poverty level, and economic development in the group's member villages; (2) financial performance, i.e., the overall financial performance of the group, including both fishery and nonfishery investments; (3) workforce development, i.e., employment, scholarships, and training supported by the group; and (4) community development plan (CDP), i.e., the degree of achievement of the entity's goals in its CDP. The state of Alaska and the CDQ entities found that the program has been a success on all four fronts (http:// alaskafisheries.noaa.gov/cdq/dreview.htm). Criteria 2 and 3 relate directly to increases in two additional categories of community capital that are theorized to provide the foundation for community resilience: human capital, i.e., knowledge base and skill sets possessed by residents; and financial capital, i.e., assets and financing available for investment. Criteria 1 and 4 show an increased ability of the communities to engage their various community capitals to achieve empowerment and well-being (Magis 2010).

\section{Community-held fishing rights: Community Quota Entity \\ Program}

The need for a similar program for small, rural communities in the Gulf of Alaska (GOA) became apparent following rationalization of the halibut and sablefish longline fisheries in 1995. Halibut has historically been a mainstay of traditional diets in both regions. However, few fishers from small, rural, predominantly Native villages were heavily invested in the commercial halibut fishery and did not receive substantial allocations of halibut/sablefish quota when these fishing privileges were first allocated (Langdon 2008). In the years following implementation of the halibut/sablefish Individual Fishing Quota (IFQ) Program, there was a further outflow of quota shares from these villages to larger hub communities in Alaska as well as out-of-state buyers (Carothers 2013). Ultimately, the Community Quota Entity (CQE) Program was established in 2004 in response to the concerns about this outflow of fishing privileges (Langdon 2008, NPFMC 2010, Carothers 2013). A total of 46 eligible communities were authorized to each create a nonprofit CQE that could purchase halibut and sablefish IFQs for lease to fishers residing in the community (NPFMC 2010, NMFS 2014). In the years following the initial creation of the CQE Program, CQE nonprofits were also authorized to purchase and lease halibut charter permits, as well as GOA nontrawl groundfish Limited License Program (LLP) permits.

The motivation behind the CQE Program was similar to that of the CDQ Program: to ensure community member participation in commercial fisheries to provide both jobs and a source of economic development revenue for communities lacking alternatives to a fisheries-based economy (Larson and Hull 1999). If successful, the CQE program could increase community resilience most directly by increasing the fisheries resources accessible to community members, i.e., natural capital. With increased employment and revenue from fisheries, ripple effects could be felt in other areas, such as greater retention of community members, i.e., social capital, and related benefits of increased participation of younger generations in the fisheries-based livelihood and culture, i.e., technical and cultural capital.

However, as of 2014, only three CQEs held commercial halibut/ sablefish IFQs and were actively leasing them to community members (https://alaskafisheries.noaa.gov/ram/cqp.htm). ${ }^{[1]}$ This reflects the program's limited success to date (Carothers 2011). Compared to the CDQ Program, which included a viable source of income that the CDQ entities could use to make investments and grow their fisheries activities and holdings, CQE-eligible communities were not provided with a revenue stream to aid initial acquisition of fishing rights (Langdon 2008, Olson 2011, Stoll and Holliday 2014). Further, a number of conditions were placed on the acquisition of quota shares by CQEs in an effort to protect existing independent fishers. In the experience of Old Harbor, a CQE community on Kodiak Island, quota shares may only be available for purchase by a CQE if there is a personal connection with a fisher willing to sell quota shares to a CQE. One decade following the inception of the CQE Program, these financial and market barriers call into question whether the present iteration of the program is achieving its goal of supporting retention and increased access to fisheries in small, rural, fishing-dependent communities in the GOA region (Langdon 2008, Carothers 2013). If adjustments are made to address start-up challenges, the program will have the potential to increase community capital, fostering both resilience as persistability and resilience as adaptability. 
Geographic landing requirements and right of first refusal: Bering Sea-Aleutian Islands Crab Rationalization and Central Gulf of Alaska Rockfish programs

Two Alaskan catch share programs, the BSAI Crab Rationalization and GOA Rockfish programs, have included community protections in the form of regional delivery requirements. In the case of the BSAI Crab Rationalization Program, two types of quota shares were allocated: harvester shares, i.e., catcher vessel owner shares, catcher-processor vessel owner shares, and crew shares, and processor quota shares (PQSs). Of the harvester quota, 90\% was designated Class A, which included regional delivery requirements, i.e., North or South, whereas the remaining $10 \%$, i.e., Class B, did not include a regional restriction. All Class $\mathrm{A}$ harvest shares are annually matched with PQSs within the delivery regions; that is, each harvester is required to sell to a specific processor depending on these matches (NPFMC 2010). In addition to regional delivery requirements, for communities that were determined to have "significant crab processing history," an ROFR was granted to community groups or CDQ entities on the sale of PQS before it could be sold to entities outside of the community (NPFMC 2010). The regulation is less complex in the case of the Central GOA Rockfish Program, which simply specifies that all deliveries must be made to processors located within the city of Kodiak (NOAA 2011).

These regional landing requirements and the ROFR provision were designed to maintain landings in historically dependent fishing communities (NPFMC 2010, Stoll and Holliday 2014). In so doing, the provisions have the potential to help sustain the fisheries-based economic engine, i.e., natural capital, that has historically been present in these communities, i.e., increasing resilience as persistability. Although a majority of processing jobs are held by migrant laborers brought in by processing companies during heavy processing seasons, the retention of processing activity in these remote communities has economic ripple effects that bolster financial capital in the community with the potential to generally increase or stabilize local economic prosperity. This may also contribute to retention of social and cultural capital if a greater number of community members choose to remain rather than migrate.

With regard to the ROFR, residents of some of the eligible communities consider this to be an unrealistic option, given prohibitive costs to acquire the processing facilities and processing rights (Lowe 2008). However, at least one community organization has exercised the right: in 2008, King Cove-based Aleutia, a seafood marketing association representing interests within the Aleutians East Borough, reached an agreement with Peter Pan Seafoods Inc. to purchase its local holdings of PQS. Peter Pan Seafoods agreed to continue processing the product and to assist with the marketing (AEB 2008).

\section{National Oceanic and Atmospheric Administration Fisheries Finance Program}

One of the primary barriers to new entry is the cost of acquiring the needed vessel, gear, and fishing rights to begin participating in a fishery. It is important to note that the cost of entry has always been very high. However, the high value of permits and quota shares since privatization has raised the financial bar on entry. In many cases, a prospective fisher may find it difficult to qualify for a traditional bank loan. In an attempt to address this, the National Oceanic and Atmospheric Administration's Fisheries Finance Program "provides long term financing for the cost of construction or reconstruction of fishing vessels, fisheries facilities, aquaculture facilities and individual fishing quota in the Northwest Halibut/Sablefish and Alaskan Crab Fisheries" (http://www.nmfs.noaa.gov/mb/financial services/ffp.htm).

In general, programs that provide financing opportunities to prospective entrants in fisheries have the potential to encourage individuals to remain in fishing communities and pursue a fishing lifestyle. The retention or addition of fishing businesses to a community can support resilience through creating or maintaining social, cultural, and human capital, as well as increasing the overall financial capital flowing into the community. These capitals may enable resilience as persistability and adaptability.

\section{Community and private-sector led resilience strategies}

Permit or license banks and quota shareholding entities

A number of entities have been created that purchase and hold fishing rights on behalf of local fishers, such as permit or license banks (e.g., Coolidge 2013, EAC 2013) and community trusts or funds (EAC 2013, MBCQF 2014; http://thealaskatrust.org/ about-local-fish-fund.php), and community fishing associations have also been considered (NEFMC 2009, Randall and Grader 2009, Stoll and Holliday 2014). Retention of active fishing businesses at the local level can stimulate the local fishing economy and culture, increasing financial, social, human, and technical capital and supporting the persistability and adaptability of the fishing community. It is essential to develop clear guidelines regarding how individual fishers will be selected as recipients of fishing rights held by a community entity. Unique allocation mechanisms have been tested, such as the case of the New Brunswick snow crab fishery. The total quota is not large enough to grant a viable portion to each member, and the Maritime Fishermen's Union uses a lottery system to grant access to a different set of fishers each year. Concerns have also been raised regarding the potential of community-held quotas to increase the cost of fishing rights (Langdon 2008, EAC 2013). Current efforts can serve as pilot studies to determine the costs and benefits of such approaches.

Financing mechanisms to facilitate new entry

A number of existing financing mechanisms can be used to provide loans to prospective and current fishers for vessel construction, upgrades, and purchase of fishing rights (e.g., Rice 2006, Klingert 2007). However, for many small-boat fishers, the cost of fishing rights in addition to the cost of boats and gear presents an insurmountable financial barrier, particularly when considering long-term uncertainty of fisheries viability (http:// thealaskatrust.org/for-the-communities.php). One example of a community-based response to this issue is the Local Fish Fund, a program of the Alaska Sustainable Fisheries Trust, which raises funds from investors to provide down payments to small-boat fishers at a rate equivalent to leasing halibut quota shares from a current quota shareholder (http://thealaskatrust.org/about-localfish-fund.php). Additional examples are the North Pacific Fishery Trust, a nonprofit subsidiary of Ecotrust, which makes fishery-related community investments, including start-up funds for CQE communities in the GOA (http://www.ecotrust.org/ 
project/npft/), and the Cape Cod Fishery Trust, which provides a revolving loan fund to assist local fishers with small vessels that want to invest in Atlantic scallop and northeast U.S. groundfish quota shares (EAC 2013). As in the example of community holding entities, an important concern related to making financing more easily accessible is that it can drive up demand and lead to increased cost of fishing privileges (Klingert 2012). Research is thus needed regarding price dynamics in response to new funding mechanisms.

\section{Succession planning: transfer of intact fishing businesses}

Retiring fishers may desire to transfer their business to their child or another younger member of their community rather than sell the pieces of their business to the highest bidder (Rice 2006, Rosvold 2007). If a fisher does not have an heir that desires to take over the business, he/she may choose to mentor another young community member to take over when the fisher retires. In addition, because of the high capital investment, many prospective fishers have difficulty financing the purchase of a complete fishing business at once (http://thealaskatrust.org/forthe-communities.php). Rather than requiring a full payment upfront, a directed transfer can be set up to take place over time, through graduated payments and a period during which the buyer becomes a part owner of the fishing business. This option requires a strong personal relationship of trust between the seller and the buyer (Rice 2006). Participant loans are available through the state of Alaska's Commercial Fishery and Agricultural Bank (CFAB) to facilitate such transactions. Buyers that may not qualify through other lenders can be granted a loan through CFAB because the seller assumes a portion of the risk of the loan based on his/her assessment of the buyer's character (Klingert 2007).

\section{Value chain improvements}

In addition to increasing access to fishing rights, fishing community resilience can be elevated through retaining a greater portion of revenues from sale of seafood at the local level. Throughout the United States, and elsewhere, nonprofit organizations have been formed around the concept of community-supported fisheries, similar to that of communitysupported agriculture, in which consumers provide up-front financing in the form of a membership fee and in return receive a portion of the harvest. This model shortens the supply chain (Andreatta and Parlier 2010, Andreatta et al. 2011, Brinson et al. 2011, Olson et al. 2014; http://thealaskatrust.org/about-localfish-fund.php; http://www.communityfisheriesnetwork.org/members. $\underline{\mathrm{html}}$ ), though it does require that fishers become licensed seafood dealers. Other avenues to increase value include marketing and branding to increase product recognition, e.g., Copper River salmon (see Simeon et al. 2011, MBCQF 2014), and other directmarketing strategies (Washburn 2001, Andreatta and Parlier 2010, Andreatta et al. 2011, Brinson et al. 2011, Olson et al. 2014).

\section{CONCLUSION}

The primary goals of contemporary U.S. fishery management efforts have been to ensure sustainable harvests and to increase economic efficiency and ease of management (Hilborn 2007). As emphasized in the MSFCMA, it is also essential to consider socioeconomic impacts that may result from shifts in the regulatory environment. We primarily consider the effects of limitations on fishery access on Alaskan fishing communities and their interactions with the issue of out-migration. A community is able to persist when it has a stable population and economic base to support the well-being of its members. Furthermore, the ability to access fisheries resources and to participate in commercial and subsistence fisheries is essential to the ability of rural Alaskan fishing communities to exist and persist in remote, isolated areas where no alternative economic opportunities are viable (NPFMC 2007, Langdon 2008).

In spite of cyclical resource uncertainty and extreme weather conditions, Alaskan fishing communities have persisted in remote, isolated areas for many generations, and thousands of years in the case of many Native villages. This has been possible in large part because of the abundance of marine and terrestrial resources and the ability of local people to opportunistically access those resources as they became available (Langdon 2008, Lowe 2008). Species switching, and the ability to shift effort away from individual fisheries during poor years, allowed local residents to diversify their livelihoods in the face of these uncertainties (Allison and Ellis 2001). The regulatory paradigm shift to private, transferable fishing rights has eroded these placebased resilience strategies; when fishing communities in Alaska lose active fishing businesses, over time the loss of a wide variety of community capitals follows. In some cases, communities are able to retain their resilience through diversification of their local economies. In other cases, no alternatives to a fishery-based economy are feasible.

Changes in large, slow variables such as the regulatory environment, climate, and global culture and markets have the capacity to destabilize Alaskan fishery SESs as they exist in their current stability domains. Indeed, many historical fishing communities have already experienced regime shifts in the form of relocation or abandonment (Wrathall 2012, Reedy-Maschner and Mascher 2013). Given this, it is of course impossible to wholly attribute the loss of capital, rural out-migration, and community abandonment trends to fisheries privatization. However, decades of research show that following fisheries privatization there is almost inevitably fleet consolidation, and the remaining fishers will generally have already made a large financial investment in vessels and gear and have the financial capital to purchase large amounts of quota. Both of these characteristics are related to a primary livelihood focus on commercial fishing. Residents of small, rural communities frequently do not possess these characteristics; they more commonly possess lower levels of financial capital overall and tend to focus on a mixture of subsistence, recreational, and/or commercial fishing. Strong impacts to these communities are thus to be expected.

The existence of the various government, private-sector, and community programs we have summarized provides acknowledgment of the socioeconomic challenges posed by changes in fishery regulations. Although some valuable programs have already been implemented, evidence suggests that Alaskan fishing communities are in need of new resilience strategies to help counteract destabilizing shifts in large-scale variables. As additional programs and strategies are developed to support retention of fisheries participation at the community level, benefits may be felt beyond just fisheries-based employment and the persistence of communities; increases in financial, social, human, political, and cultural capital that accompany a vibrant 
fisheries sector can equip communities with resources to adapt and transform in the face of an increasing array of large-scale changes.

${ }^{[1]}$ Although only 3 CQEs held halibut/sablefish IFQs as of August 2014, 21 CQEs did hold halibut charter permits, and 4 CQEs held nontrawl groundfish LLPs for use by community members (http:// www.nmfs.noaa.gov/mb/financial services/ffp.htm).

Responses to this article can be read online at: http://www.ecologyandsociety.org/issues/responses. $\mathrm{php} / 7074$

\section{Acknowledgments: \\ We would like to thank the following people for their valuable input in the review of this manuscript: Ron Felthoven, Steve Kasperski, Patricia Clay, and Richard Pollnac.}

\section{LITERATURE CITED}

Abbott, J. K., B. Garber-Yonts, and J. E. Wilen. 2010. Employment and remuneration effects of IFQs in the Bering Sea/ Aleutian Islands crab fisheries. Marine Resource Economics 25 (4):333-354. http://dx.doi.org/10.5950/0738-1360-25.4.333

Adger, W. N. 2006. Vulnerability. Global Environmental Change 16(3):268-281. http://dx.doi.org/10.1016/j.gloenvcha.2006.02.006

Alaska Department of Labor and Workforce Development (ADL). 2013. Alaska population overview: 2012 estimates. ADL, Juneau, Alaska, USA. [online] URL: http://almis.labor.state.ak. us/pop/estimates/pub/12popover.pdf

Aleutians East Borough (AEB). 2008. Aleutia provides community protection for the city of King Cove. 29 July. AEB, Anchorage, Alaska, USA. [online] URL: http://www.aleutianseast.org/index. asp? Type $=$ B PR\&SEC $=\%$ 7B4625D388-43A1-4E17-A354F5F12E4E7205\%7D\&DE $=\%$ 7BE164DFC4-9349-48D0-93FBD3277B0F3FEC \%7D

Allison, E. H., and F. Ellis. 2001. The livelihoods approach and management of small-scale fisheries. Marine Policy 25:377-388. http://dx.doi.org/10.1016/S0308-597X(01)00023-9

Andreatta, S., B. Nash, and G. B. Martin. 2011. Carteret Catch ${ }^{\mathrm{TM}}$ : promoting local seafood through community and business partnerships. Human Organization 70(3):279-288.

Andreatta, S., and A. Parlier. 2010. The political ecology of smallscale commercial fishermen in Carteret County, North Carolina. Human Organization 69(2):180-191.

Bader, H. 1998. Who has the legal right to fish? Constitutional and common law in Alaska fisheries management. University of Alaska Sea Grant College Program, Anchorage, Alaska, USA.

Berardi, G. 1999. Schools, settlement, and sanitation in Alaska Native villages. Ethnohistory 46(2):329-359.

Berkes, F., and D. Jolly. 2001. Adapting to climate change: socialecological resilience in a Canadian western Arctic community. Conservation Ecology 5(2): 18. [online] URL: http://www. consecol.org/vol5/iss2/art18/
Berkes, F., and C. S. Seixas. 2005. Building resilience in lagoon social-ecological systems: a local-level perspective. Ecosystems 8:967-974. http://dx.doi.org/10.1007/s10021-005-0140-4

Bjarnason, T., and T. Thorlindsson. 2006. Should I stay or should I go? Migration expectations among youth in Icelandic fishing and farming communities. Journal of Rural Studies 22:290-300. http://dx.doi.org/10.1016/j.jrurstud.2005.09.004

Black, R., W. N. Adger, N. W. Arnell, S. Dercon, A. Geddes, and D. Thomas. 2011. The effect of environmental change on human migration. Global Environmental Change 21(Supplement 1):S3S11. http://dx.doi.org/10.1016/j.gloenvcha.2011.10.001

Brand, F. S., and K. Jax. 2007. Focusing on meaning(s) of resilience: resilience as a descriptive concept and a boundary object. Ecology and Society 12(1): 23. [online] URL: http://www. ecologyandsociety.org/vol12/iss1/art23/

Brinson A., M.-Y. Lee, and B. Rountree. 2011. Direct marketing strategies: the rise of community supported fishery programs. Marine Policy 35(4):542-548. http://dx.doi.org/10.1016/j. marpol.2011.01.014

Carothers, C. 2008. "Rationalized out": discourses and realities of fisheries privatization in Kodiak, Alaska. Pages 55-74 in M. E. Lowe and C. Carothers, editors. Enclosing the fisheries: people, places, and power. Symposium 68. American Fisheries Society, Bethesda, Maryland, USA.

Carothers, C. 2010. Tragedy of commodification: displacements in Alutiiq fishing communities in the Gulf of Alaska. MAST 9 (2):95-120.

Carothers, C. 2011. Equity and access to fishing rights: exploring the Community Quota Program in the Gulf of Alaska. Human Organization 70(3):213-223.

Carothers, C. 2013. A survey of US halibut IFQ holders: market participation, attitudes, and impacts. Marine Policy 38:515-522. http://dx.doi.org/10.1016/j.marpol.2012.08.007

Carothers, C., and C. Chambers. 2012. Fisheries privatization and the remaking of fishery systems. Environment and Society: Advances in Research 3:39-59. http://dx.doi.org/10.3167/ ares.2012.030104

Carothers, C., D. K. Lew, and J. Sepez. 2010. Fishing rights and small communities: Alaska halibut IFQ transfer patterns. Ocean \& Coastal Management 53:518-523. http://dx.doi.org/10.1016/j. ocecoaman.2010.04.014

Clark, C. W. 1980. Towards a predictive model for the economic regulation of commercial fisheries. Canadian Journal of Fisheries and Aquatic Science 37(7):1111-1129. http://dx.doi.org/10.1139/ $\underline{\text { f80-144 }}$

Clay, P. M. 2007. Defining fishing communities: issues in theory and practice. Annals of Anthropological Practice 28(1):27-42. http://dx.doi.org/10.1525/napa.2007.28.1.27

Clay, P. M., and J. Olson. 2008. Defining "fishing communities": vulnerability and the Magnuson-Stevens Fishery Conservation and Management Act. Human Ecology Review 15(2):143-160.

Clay, P. M., P. Pinto da Silva, and A. Kitts. 2010. Defining social and economic performance measures for catch share systems in the Northeast U.S. In Proceedings of the Fifteenth Biennial 
Conference of the International Institute of Fisheries Economics \& Trade: economics of fish resources and aquatic ecosystems: balancing uses, balancing costs (Montpellier, France, 13-16 July 2010). International Institute of Fisheries Economics \& Trade, Corvallis, Oregon, USA. [online] URL: http://www.nefsc.noaa. gov/read/socialsci/pdf/publications/IIFET2010-PMC-PPDS-AKrevised $\% 20$ gfish $\% 20$ list.pdf

Clayton, K. 2014. Alaska and world seafood market expert encourages Petersburg to adapt. Petersburg Pilot 40(11), 13 March.

Coolidge, D. 2013. Opinion: Bristol Bay should re-examine current permit buyback program. Bristol Bay Times, 13 July. [online] URL: http://www.thebristolbaytimes.com/ article/1328bristol bay should re-examine current permit

Corbett, M. 2004. "It was fine, if you wanted to leave": educational ambivalence in a Nova Scotian coastal community 1963-1998. Anthropology \& Education Quarterly 35(4):451-471. http://dx.doi.org/10.1525/aeq.2004.35.4.451

Corbett, M. 2005. Rural education and out-migration: the case of a coastal community. Canadian Journal of Education 28 (1/2):52-72. http://dx.doi.org/10.2307/1602153

Costello, C., S. D. Gaines, and J. Lynham. 2008. Can catch shares prevent fisheries collapse? Science 321(5896):1678-1681. http:// dx.doi.org/10.1126/science. 1159478

Coulthard, S. 2012. Can we be both resilient and well, and what choices do people have? Incorporating agency into the resilience debate from a fisheries perspective. Ecology and Society 17(1): 4. http://dx.doi.org/10.5751/ES-04483-170104

Davidson, D. J. 2010. The applicability of the concept of resilience to social systems: some sources of optimism and nagging doubts. Society \& Natural Resources: An International Journal 23 (12):1135-1149. http://dx.doi.org/10.1080/08941921003652940

Department of Commerce, Community and Economic Development (DCCED). 2009. Alaska's rural population and school population trends: a discussion of its components. Report 1. DCCED, Anchorage, Alaska, USA. [online] URL: http://www. commerce.state.ak.us/dcra/pub/rural to urban migration2.pdf

Donkersloot, R. 2005. Ecological crisis, social change and the life paths of young Alaskans: an analysis of the impacts of shifting patterns in human-environment interactions in the fisheries dependent region of Bristol Bay, Alaska. Thesis. University of Montana, Missoula, Montana, USA.

Donkersloot, R. 2006. Downloading the death knell? Negotiating capital, resource and reason in B.C. fisheries. Ethnographic Field School, University of British Columbia, Vancouver, British Columbia, Canada.

Ecology Action Centre (EAC). 2013. Social impact investing for sustainable fishing communities: workshop report. Report No. eac-062. EAC, Halifax, Nova Scotia, Canada.

Emery, M., and C. Flora. 2006. Spiraling-up: mapping community transformation with community capitals framework. Community Development 37(1):19-35. http://dx.doi. org/10.1080/15575330609490152
Etuk, L., M. Keen, and C. Wall. 2012. The factors associated with rural community success: a review of rural community vitality research. Oregon State University, Corvallis, Oregon, USA.

Fina, M. 2011. Evolution of catch share management: lessons from catch share management in the North Pacific. Fisheries 36 (4):164-177. http://dx.doi.org/10.1080/03632415.2011.564509

Folke, C., S. R. Carpenter, B. Walker, M. Scheffer, T. Chapin, and J. Rockström. 2010. Resilience thinking: integrating resilience, adaptability and transformability. Ecology and Society 15(4): 20. [online] URL: http://www.ecologyandsociety.org/vol15/iss4/ art20/

Fowler, K., and H. Etchegary. 2008. Economic crisis and social capital: the story of two rural fishing communities. Journal of Occupational and Organizational Psychology 81:319-341. http:// dx.doi.org/10.1348/096317907X226972

Ginter, J. J. C. 1995. The Alaska community development quota fisheries management program. Ocean \& Coastal Management 28 (1-3):147-163. http://dx.doi.org/10.1016/0964-5691(95)00069-0

Ginter, J. J. C., and B. Muse. 2003. Rights-based fishery management systems in marine fisheries off Alaska. In Proceedings of the Eleventh Biennial Conference of the International Institute of Fisheries Economics and Trade: fisheries in the global economy (Wellington, New Zealand, 19-22 August 2002). International Institute of Fisheries Economics and Trade, Corvallis, Oregon, USA.

Gordon, H. S. 1954. The economic theory of a common-property resource: the fishery. Journal of Political Economy 62(2):124-142. http://dx.doi.org/10.1086/257497

Graton, R. Q., D. Squires, and J. E. Kirkley. 1996. Private property rights and crises in world fisheries: turning the tide? Contemporary Economic Policy 14(4):90-99.

Greer, J. 1995. The big business takeover of US fisheries: privatizing the oceans through individual transferable quotas (ITQs). Greenpeace, Washington, D.C., USA.

Hadland, J. 2004. Alaska's ‘brain drain': myth or reality? Monthly Labor Review 127(5):9-22.

Hamilton, L. C., C. R. Colocousis, and S. T. F. Johansen. 2004. Migration from resource depletion: the case of the Faroe Islands. Society \& Natural Resources: An International Journal 17 (5):443-453. http://dx.doi.org/10.1080/08941920490430232

Hamilton, L. C., and R. L. Haedrich. 1999. Ecological and population changes in fishing communities of the North Atlantic Arc. Polar Research 18(2):383-388. http://dx.doi.org/10.1111/ j.1751-8369.1999.tb00318.x

Hamilton, L. C., and O. Otterstad. 1998. Demographic change and fisheries dependence in the northern Atlantic. Human Ecology Review 5(2):16-22.

Haynie, A. C. 2014. Changing usage and value in the Western Alaska Community Development Quota (CDQ) Program. Fisheries Science 80(2):181-191. http://dx.doi.org/10.1007/ $\underline{\mathrm{s} 12562-014-0723-0}$

Healey, M. C. 2009. Resilient salmon, resilient fisheries for British Columbia, Canada. Ecology and Society 14(1): 2. [online] URL: http://www.ecologyandsociety.org/vol14/iss1/art2/ 
Hilborn, R. 2007. Defining success in fisheries and conflicts in objectives. Marine Policy 31:153-158. http://dx.doi.org/10.1016/j. marpol.2006.05.014

Himes-Cornell, A., K. Hoelting, C. Maguire, L. Munger-Little, J. Lee, J. Fisk, R. Felthoven, C. Geller, and P. Little, P. 2013. Community profiles for North Pacific Fisheries - Alaska. National Oceanic and Atmospheric Association (NOAA) Technical Memorandum NMFS-AFSC-259, Volumes 1-12. U.S. Department of Commerce, NOAA, Washington, D.C., USA. [online] URL: http://www.afsc.noaa.gov/publications/afsc-tm/noaa-tm-afsc-259/ noaa-tm-afsc-259-complete.pdf

Holling, C. S., and L. H. Gunderson. 2002. Resilience and adaptive cycles. Pages 25-62 in L. H. Gunderson and C. S. Holling, editors. Panarchy: understanding transformations in human and natural systems. Island, Washington, D.C., USA.

Homan, F. 2007. State limited entry. Presented at Alaska Young Fishermen's Summit: weaving a network of future fishing leaders (25-26 January 2007). Commercial Fisheries Entry Commission, State of Alaska, Juneau, Alaska, USA. [online] URL: http://www. cfec.state.ak.us/pregs/StateLimitedEntry.pdf

Howe, E. L. 2009. Patterns of migration in Arctic Alaska. Polar Geography 32(1-2):69-89. http://dx.doi.org/10.1080/10889370903000422

Huskey, L. 2009. Community migration in Alaska's north: the places people stay and the places they leave. Polar Geography 32 (1-2):17-30. http://dx.doi.org/10.1080/10889370903000448

Huskey, L., M. Berman, and A. Hill. 2004. Leaving home, returning home: migration as a labor market choice for Alaska Natives. Annals of Regional Science 38:75-92. http://dx.doi. org/10.1007/s00168-003-0141-1

Jentoft, S. 2000. The community: a missing link of fisheries management. Marine Policy 24:53-60. http://dx.doi.org/10.1016/ $\underline{\text { S0308-597X(99)00009-3 }}$

Kasperski, S., and D. S. Holland. 2013. Income diversification and risk for fishermen. Proceedings of the National Academy of Sciences of the United States of America 110(6):2076-2081. http:// dx.doi.org/10.1073/pnas.1212278110

Keck, M., and P. Sakdapolrak. 2013. What is social resilience? Lessons learned and ways forward. Erdkunde 67(1):5-19. http:// dx.doi.org/10.3112/erdkunde.2013.01.02

Kelty, R., and R. Kelty. 2011. Human dimensions of a fishery at a crossroads: resource valuation, identity, and way of life in a seasonal fishing community. Society \& Natural Resources: An International Journal 24(4):334-348. http://dx.doi. org/10.1080/08941920903476814

Kirmayer, L. J., M. Sehdev, R. Whitley, S. F. Dandeneau, and C. Isaac. 2009. Community resilience: models, metaphors and measures. Journal of Aboriginal Health 5:62-117.

Klingert, L. 2007. Commercial fishing and agriculture bank. Pages 91-93 in P. Cullenberg, editor. Alaska's fishing communities: harvesting the future. University of Alaska Fairbanks, Alaska Sea Grant College Program, Fairbanks, Alaska, USA.

Klingert, L. E. 2012. Letter from the Alaska Commercial Fishing and Agricultural Bank (CFAB) to the Finance Committee,
Alaska House of Representatives regarding HB 261, 25 January 2012. CFAB, Anchorage, Alaska, USA. [online] URL: http:// www.legis.state.ak.us/basis/get_documents.asp? session $=27 \&$ docid $=10485$

Knapp, G. 2007. The Chignik salmon cooperative: a case study of allocation to a voluntary self-governance organization. Working Paper. Institute of Social and Economic Research, University of Alaska Anchorage, Anchorage, Alaska, USA.

Knapp, G. 2011. Local permit ownership in Alaska salmon fisheries. Marine Policy 35(5):658-666. http://dx.doi.org/10.1016/ j.marpol.2011.02.006

Langdon, S. J. 1995. Increments, ranges, and thresholds: human population responses to climate change in northern Alaska. Pages 139-154 in D. L. Peterson and D. R. Johnson, editors. Human ecology and climate change: people and resources in the Far North. Taylor and Francis, Washington, D.C., USA.

Langdon, S. J. 2008. The Community Quota Program in the Gulf of Alaska: a vehicle for Alaska Native village sustainability. Pages 155-194 in M. E. Lowe and C. Carothers, editors. Enclosing the fisheries: people, places, and power. Symposium 68. American Fisheries Society, Bethesda, Maryland, USA.

Larson, E., and T. Hull. 1999. Gulf of Alaska coastal communities: an overview. Institute of Social and Economic Research, University of Alaska Anchorage, Anchorage, Alaska, USA.

Lowe, M. E. 2008. Crab rationalization and potential community impacts of vertical integration in Alaska's fisheries. Pages 119-154 in M. E. Lowe and C. Carothers, editors. Enclosing the fisheries: people, places, and power. Symposium 68. American Fisheries Society, Bethesda, Maryland, USA.

Lowe, M. E. 2012. Alaska coastal community youth and the future. Institute of Social and Economic Research, University of Alaska Anchorage, Anchorage, Alaska, USA.

Macinko, S. 1993. Public or private: United States commercial fisheries management and the public trust doctrine, reciprocal challenges. Natural Resources Journal 33:919-955.

Magis, K. 2010. Community resilience: an indicator of social sustainability. Society \& Natural Resources: An International Journal 23(5):401-416. http://dx.doi.org/10.1080/08941920903305674

Magnuson-Stevens Fishery Conservation and Management Reauthorization Act of 2006. Definitions: fishing community. 16 U.S.C. $1802 \S 3(17)$.

Magnuson-Stevens Fishery Conservation and Management Reauthorization Act of 2006. National Standard 8. 16 U.S.C. $\S 1851(\mathrm{a})(8)$.

Mansfield, B. 2004. Neoliberalism in the oceans: "rationalization," property rights, and the commons question. Geoforum 35 (3):313-326. http://dx.doi.org/10.1016/j.geoforum.2003.05.002

Mantua, N., and R. C. Francis. 2004. Natural climate insurance for Pacific Northwest salmon: finding our way through the entangled bank. American Fisheries Society Symposium 43:121-134.

Marschke, M., and F. Berkes. 2006. Exploring strategies that build livelihood resilience: a case from Cambodia. Ecology and Society 11(1): 42. [online] URL: http://www.ecologyandsociety.org/ vol11/iss1/art42/ 
Marshall, N. A., D. M. Fenton, P. A. Marshall, and S. G. Sutton. 2007. How resource dependency can influence social resilience within a primary resource industry. Rural Sociology 72 (3):359-390.

Marshall, N. A., and P. A. Marshall. 2007. Conceptualizing and operationalizing social resilience within commercial fisheries in northern Australia. Ecology and Society 12(1): 1. [online] URL: http://www.ecologyandsociety.org/vol12/iss1/art1/

Martin, I. E. 2008. Resilience in Lower Columbia River salmon communities. Ecology and Society 13(2): 23. [online] URL: http:// www.ecologyandsociety.org/vol13/iss2/art23/

Martin, S. 2009. The effects of female out-migration on Alaska villages. Polar Geography 32(1-2):61-67. http://dx.doi. org/10.1080/10889370903000455

Martin, S., M. Killorin, and S. Colt. 2008. Fuel costs, migration, and community viability: final report. Institute of Social and Economic Research, University of Alaska Anchorage, Anchorage, Alaska, USA.

Martin-Breen, P., and J. M. Anderies. 2011. Resilience: a literature review. Rockefeller Foundation, New York, New York, USA. [online] URL: http://www.rockefellerfoundation.org/blog/resilienceliterature-review

McLeman, R. A. 2011. Settlement abandonment in the context of global environmental change. Global Environmental Change 21 (Supplement 1):S108-S120. http://dx.doi.org/10.1016/j. gloenvcha.2011.08.004

Mederer, H. J., and C. Barker. 2000. Reconstructing identities, families, communities, and futures in the wake of fisheries regulation. Pages 69-81 in S. Hanna and M. Hall-Arber, editors. Change and resilience in fishing. Oregon State University Press, Corvallis, Oregon, USA.

Morrissey, M. T. 2008. Global resources and market impacts on US Pacific Northwest fisheries. Globalization 5(2):195-210. http:// dx.doi.org/10.1080/14747730802057571

Morrow Bay Community Quota Fund (MBCQF). 2014. Home. 10 July. MBCQF, Morrow Bay, California, USA. [online] URL: http://www.morrobaycommunityquotafund.org/

National Marine Fisheries Service (NMFS). 2008. National Standard 8: communities. 50 C.F.R. Ch. VI (10-1-02 edition) $\S 600.345(\mathrm{~b})(3)$.

National Marine Fisheries Service (NMFS). 2014. Table 21 to part 679 - eligible communities, Halibut IFQ Regulatory Area location, community governing body that recommends the CQE, and the fishing programs and associated areas where a CQE representing an eligible community may be permitted to participate. U.S. Department of Commerce, National Oceanic and Atmospheric Association, Washington, D.C., USA. [online] URL: https://alaskafisheries.noaa.gov/rr/tables/tabl21.pdf

National Oceanic and Atmospheric Association (NOAA). 2011. 50 CFR Part 679. Fisheries of the exclusive economic zone off Alaska; groundfish of the Gulf of Alaska; amendment 88. Federal Register 76(248):81248-81293.

National Research Council (NRC). 1999. The Community Development Quota Program in Alaska. National Academy, Washington, D.C., USA.
New England Fishery Management Council (NEFMC). 2010. Amendment 15 to the scallop fishery management plan. NEFMC, Newbury Port, Massachusetts, USA. [online] URL: http:// archive.nefmc.org/scallops/planamen/a15/110111\%20A15 FEIS final $\%$ 20.pdf

North Pacific Fishery Management Council (NPFMC). 2002. Regulatory impact review/initial regulatory flexibility analysis: public review draft for proposed amendment 71 to the fishery management plan for Bering SealAleutian Islands groundfish to implement policy and administrative changes to the Western Alaska Community Development Program. NPFMC, Anchorage, Alaska, USA.

North Pacific Fishery Management Council (NPFMC). 2007. Aleutian Islands fishery ecosystem plan: December 2007. NPFMC, Anchorage, Alaska, USA. [online] URL: http://www.npfmc.org/ wp-content/PDFdocuments/conservation_issues/AIFEP/AIFEP12 07. pdf

North Pacific Fishery Management Council (NPFMC). 2010. Review of the Community Quota Entity (CQE) Program under the halibut/sablefish IFQ Program. NPFMC, Anchorage, Alaska, USA. [online] URL: http://www.npfmc.org/wp-content/PDFdocuments/ halibut/CQEreport210.pdf

Olson, J. 2011. Understanding and contextualizing social impacts from the privatization of fisheries: an overview. Ocean \& Coastal Management 54:353-363. http://dx.doi.org/10.1016/j. ocecoaman.2011.02.002

Olson, J., P. M. Clay, and P. Pinto da Silva. 2014. Putting the seafood in sustainable food systems. Marine Policy 43:104-111. http://dx.doi.org/10.1016/j.marpol.2013.05.001

Package-Ward, C., and A. Himes-Cornell. 2014. Utilizing oral histories to understand the social networks of Oregon fishermen in Alaska. Human Organization 73(3):277-288.

Pinkerton, E., and D. N. Edwards. 2009. The elephant in the room: the hidden costs of leasing individual transferable fishing quotas. Marine Policy 33(4):707-713. http://dx.doi.org/10.1016/j. marpol.2009.02.004

Pollnac, R. B., and J. J. Poggie. 2006. Job satisfaction in the fishery in two southeast Alaskan towns. Human Organization 65 (3):329-339.

Pollnac, R. B., and J. J. Poggie. 2008. Happiness, well-being and psychocultural adaptation to the stresses associated with marine fishing. Human Ecology Review 15(2):194-200.

Portes, A. 1998. Social capital: its origins and applications in modern sociology. Annual Review of Sociology 24:1-24. http://dx. doi.org/10.1146/annurev.soc.24.1.1

Randall, S., and N. Grader. 2009. Community fishing associations: a new way forward. Fishermen's News, March 2009. Pacific Coast Federation of Fisherman's Associations, San Francisco, California, USA. [online] URL: http://www.pcffa.org/ fn-mar09.htm

Reedy-Maschner, K. L. 2008. Eastern Aleut society under three decades of limited entry. Pages 13-34 in M. E. Lowe and C. Carothers, editors. Enclosing the fisheries: people, places, and power. Symposium 68. American Fisheries Society, Bethesda, Maryland, USA. 
Reedy-Maschner, K. L., and H. D. G. Maschner. 2013. Sustaining Sanak Island, Alaska: a cultural land trust. Sustainability 5:4406-4427. http://dx.doi.org/10.3390/su5104406

Rice, S. 2006. How to make a directed transfer of your fishing business. Alaska Sea Grant Marine Advisory Program, University of Alaska Fairbanks, Fairbanks, Alaska, USA. [online] URL: https://seagrant.uaf.edu/map/fishbiz/pubs/directedtransfer.pdf

Robards, M., and L. Alessa. 2004. Timescapes of community resilience and vulnerability in the circumpolar North. Arctic 57 (4):415-427. http://dx. doi.org/10.14430/arctic518

Robards, M. D., and J. A. Greenberg. 2007. Global constraints on rural fishing communities: whose resilience is it anyway? Fish and Fisheries 8:14-30. http://dx.doi.org/10.1111/j.1467-2979.2007.00231. $\underline{\mathrm{x}}$

Robson, J. P., and P. K. Nayak. 2010. Rural out-migration and resource-dependent communities in Mexico and India. Population and Environment 32:263-284. http://dx.doi.org/10.1007/ s11111-010-0121-1

Rolfe, R. E. 2006. Social cohesion and community resilience: a multi-disciplinary review of literature for rural health research. Rural Centre, Halifax, Nova Scotia, Canada.

Rosvold, E. 2007. Graying of the fleet: community impacts from asset transfers. Pages 67-72 in P. Cullenberg, editor. Alaska's fishing communities: harvesting the future. Alaska Sea Grant College Program, University of Alaska Fairbanks, Fairbanks, Alaska, USA.

Scheffer, M., S. Carpenter, J. A. Foley, C. Folke, and B. Walker. 2001. Catastrophic shifts in ecosystems. Nature 413:591-596. http://dx.doi.org/10.1038/35098000

Scott, A. 1955. The fishery: the objectives of sole ownership. Journal of Political Economy 63:116-124. http://dx.doi. org/10.1086/257653

Simeon, W. E., L. C. Naves, M. E. Lowe, G. Stickwan, E. M. Valentine, and J. Brady. 2011. Cultural models of Copper River salmon fisheries. Technical Paper No. 351. Alaska Department of Fish and Game, Division of Subsistence, Anchorage, Alaska, USA. [online] URL: http://doc.nprb.org/web/08 prjs/823 final $\%$ 20report ADGF\%20Technical\%20Paper.pdf

Stockdale, A. 2004. Rural out-migration: community consequences and individual migrant experiences. Sociologia Ruralis 44(2):167-194. http://dx.doi.org/10.1111/j.1467-9523.2004.00269. $\underline{\mathrm{x}}$

Stoll, J. S., and M. C. Holliday. 2014. The design and use of fishing community and regional fishery association entities in limited access privilege programs. National Oceanic and Atmospheric Association (NOAA) Technical Memorandum NMFS-F/ SPO-138. U.S. Department of Commerce, NOAA, Washington, D.C., USA.

Turner, B. L., II, R. E. Kasperson, P. A. Matson, J. J. McCarthy, R. W. Corell, L. Christensen, N. Eckley, J. X. Kasperson, A. Luers, M. L. Martello, C. Polsky, A. Pulsipher, and A. Schiller. 2003. A framework for vulnerability analysis in sustainability science.
Proceedings of the National Academy of Sciences of the United States of America 100(14):8074-8079. http://dx.doi.org/10.1073/ pnas. 1231335100

U.S. General Accounting Office (GAO). 2004. Individual fishing quotas: methods for community protection and new entry require periodic evaluation. Report to Congressional Requesters, GAO-04-277. GAO, Washington, D.C., USA.

Walker, B., C. S. Holling, S. R. Carpenter, and A. Kinzig. 2004. Resilience, adaptability and transformability in social-ecological systems. Ecology and Society 9(2): 5. [online] URL: http://www. ecologyandsociety.org/vol9/iss2/art5/

Washburn, M. 2001. Direct marketing of seafood: a fisherman's perspective. In Proceedings of the Tenth Biennial Conference of the International Institute of Fisheries Economics and Trade: microbehavior and macroresults (Corvallis, Oregon, 10-14 July 2000). International Institute of Fisheries Economics and Trade, Corvallis, Oregon, USA.

Windle, M. J. S., B. Neis, S. Bornstein, M. Binkley, and P. Navarro. 2008. Fishing occupational health and safety: a comparison of regulatory regimes and safety outcomes in six countries. Marine Policy 32(4):701-710. http://dx.doi.org/10.1016/j.marpol.2007.12.003

Winkler, R., C. Cheng, and S. Golding. 2012. Boom or bust? Population dynamics in natural resource-dependent counties. Pages 349-367 in L. J. Kulcsár and K. J. Curtis, editors. International handbook of rural demography. Springer, Dordrecht, Netherlands. http://dx.doi.org/10.1007/978-94-007-1842-5 24

Wrathall, D. J. 2012. Migration amidst social-ecological regime shift: the search for stability in Garifuna villages of northern Honduras. Human Ecology 40(4):583-596. http://dx.doi. org/10.1007/s10745-012-9501-8

Yandle, T., and C. M. Dewees. 2003. Privatizing the commons ... twelve years later: fishers' experiences with New Zealand's market-based fisheries management. Pages 101-128 in N. Dolšak and E. Ostrom, editors. The Commons in the new millennium: challenges and adaptations. Massachusetts Institute of Technology, Boston, Massachusetts, USA. 